\title{
HORIZONTES ICONOGRÁFICOS EN VENEZUELA: DIFERENCIAS REGIONALES E HISTÓRICAS
}

\author{
ICONOGRAPHIC HORIZONS IN VENEZUELA: REGIONAL AND \\ HISTORIC DIFFERENCES
}

\author{
Alessandra Caputo JafFé
}

El artículo explora las tradiciones iconográficas del Período Prehispánico halladas en territorios de la actual Venezuela. A nivel arqueológico y etnográfico se identifica una mayor presencia de estatuillas de uso votivo en el septentrión venezolano, mientras que al sur del Orinoco prácticamente no se han encontrado vestigios de aquellas. Las crónicas de los Períodos Colonial y Republicano ya documentan estas diferencias, remarcando las prácticas idolátricas en el norte y la ausencia de idolatría en el sur. Por ello, proponemos la presencia de horizontes iconográficos u ontologías visuales que discurren de forma independiente de la estilística alfarera o las familias lingüísticas.

Palabras clave: estatuillas votivas, iconografía indígena, colonización, idolatría, Venezuela, horizontes iconográficos.

This article explores the iconographic traditions of the PreHispanic Period in the territory of what is now Venezuela. While archaeological and ethnographic votive statuettes are abundant in Northern Venezuela, south of the Orinoco River hardly any trace of those objects has been found. Chronicles from the Colonial and Republican periods have already documented that difference, highlighting the presence of idolatrous practices in the north and an absence of idolatry in the south. Given this scenario, in this article we attempt to identify the presence of iconographic horizons or visual ontologies that are independent of ceramic styles or linguistic families.

Keywords: votive statuettes, Indigenous iconography, colonization, idolatry, Venezuela, iconographic horizons.

\section{INTRODUCCIÓN}

Las sociedades amerindias que habitaron durante el Período Prehispánico y Colonial en las regiones que hoy conforman Venezuela constituyen un fértil campo de trabajo para comprender los distintos lenguajes visuales relacionados con las prácticas votivas del pasado. Los territorios que engloban una parte continental del Caribe, del norte del Amazonas, así como el extremo norte de la cordillera de los Andes y su piedemonte, no solo fueron habitados por culturas pertenecientes a diversas familias lingüísticas que se expanden por América Latina, como la Arawak, la Caribe, la macroChibcha, así como otras lenguas independientes. En estas áreas, asimismo, confluyen significativamente diversos lenguajes plásticos que nos hablan de posibles sistemas simbólicos que aquí denominaremos horizontes iconográficos. Esta denominación obedece a que se trata de formas particulares de concebir visualmente el mundo, formas que se expanden en el tiempo y en el espacio. En ellas, podemos identificar algunas constantes que se desplazan y propagan en diversos lugares y períodos, además de ser independientes de los estilos visuales, que distinguen diversos grupos humanos (fig. 1).

\footnotetext{
A Alessandra Caputo Jaffé, Universidad de Chile, Proyecto Postdoctorado Fondecyt Nº 3150061, Chile e-mail: alessandra.caputo@gmail.com
} 


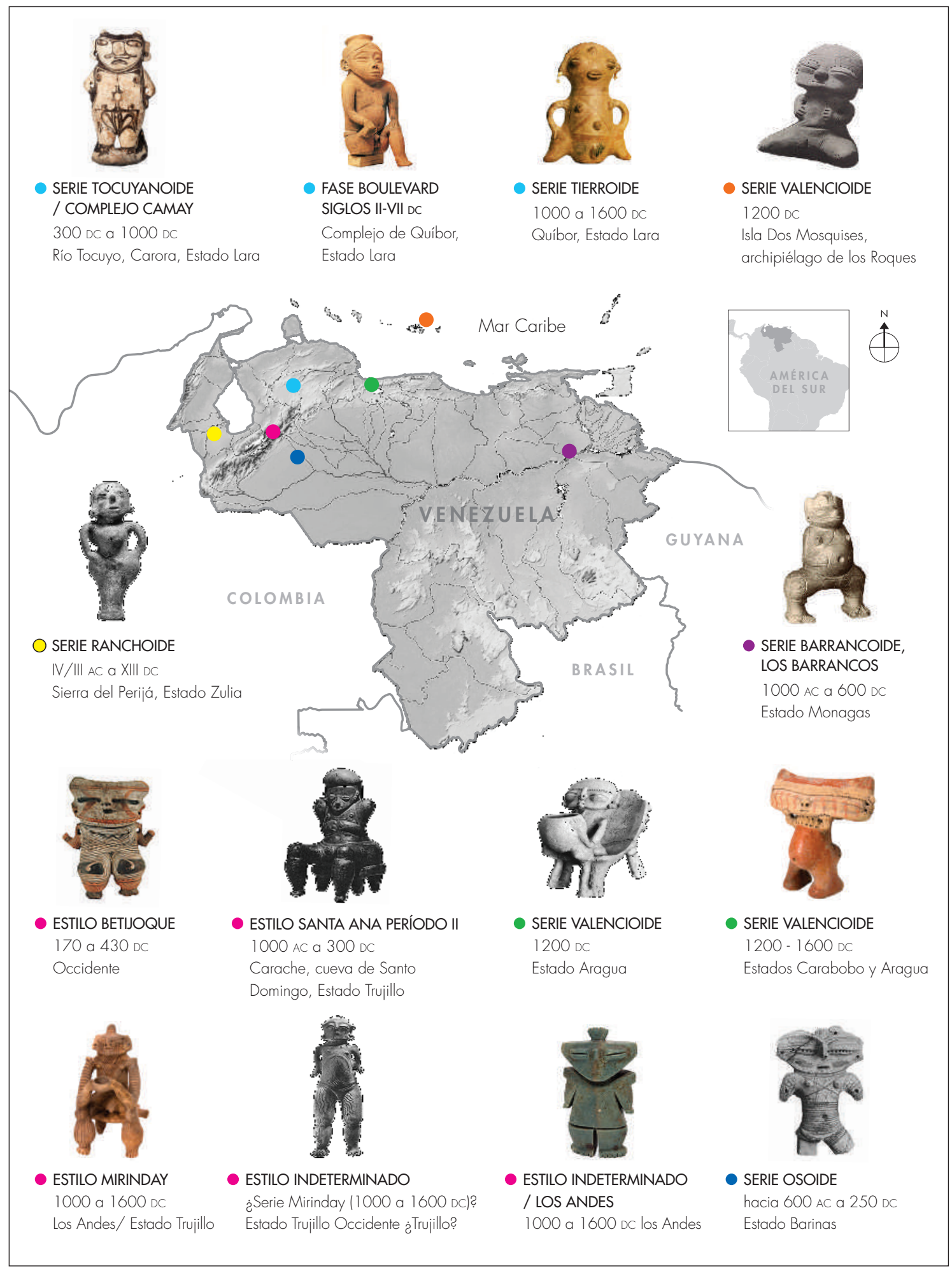

Figura 1. Distribución de estatuillas precolombinas, femeninas y chamánicas, según estilo alfarero. Figure 1. Pre-Columbian female and shamanic statuettes, by pottery style. 
En este sentido, nos percatamos de que algunas sociedades se caracterizaron por poseer una prolífica cultura visual ceremonial, con gran cantidad de figuraciones zoo y antropomorfas que toman el cuerpo de estatuillas (de cerámica, piedra o madera, por ejemplo), mientras que otras, en cambio, desarrollaron una cultura visual cuyas representaciones icónicas son más geométrico-abstractas y se plasman en materiales menos perdurables, como la cestería. A pesar de conjugarse a través de formas geométricas, estas últimas también corresponden a un modo de manifestar complejos símbolos visuales que refieren a los conocimientos míticos y valores sagrados.

Como primer punto, identificaremos diversos horizontes iconográficos que se encuentran en las regiones que conforman la cuenca del Orinoco y adyacencias, esclareciendo previamente sus criterios de selección y la acepción del concepto de iconografía implementado. El estudio de estas formas de concepción iconográfica se ubica así como una línea paralela o simultánea a las categorizaciones existentes entre grupos estilísticos y lingüísticos comúnmente asociados por la arqueología venezolana (Rouse \& Cruxent 1963; Wagner 1999; Arvelo 1999: 110-111). Sostenemos que en este espacio la expansión de cultos que recurrían al uso de estatuillas votivas se mueve de manera independiente respecto a las líneas de movimiento lingüísticas y estilísticas en la alfarería.

Como segundo punto, mostraremos en qué medida estas iconografías manifestadas a través de estatuillas de cerámica solo se desarrollaron en el septentrión venezolano (desde las estribaciones andinas hasta el Estado Monagas), mientras que encontramos un tipo de representación icónica muy diferente al sur del Orinoco -es decir, en la región del macizo guayanés y Amazonas venezolano-, correspondiente a la cuenca del río. Así, en la cultura material amerindia del pasado prehispánico se puede apreciar, por un lado, un horizonte iconográfico-figurativo en las costas del Caribe, los Andes, sus estribaciones y los llanos del noroccidente; y por otro, un horizonte iconográfico más geométrico-abstracto entre las culturas orinoquenses. No pretendemos, en todo caso, realizar un estudio exhaustivo de uno de ellos o de un período específico, sino que esperamos ofrecer una vista panorámica de las relaciones que mantuvieron a lo largo del tiempo y el espacio.

Asimismo, remarcaremos las repercusiones que durante la Colonia tuvieron las diferencias formales y simbólicas en las prácticas visuales prehispánicas y en las posibilidades de "sobrevivir" a los procesos de colonización y evangelización. Las culturas del norte habitaban precisamente las regiones que más adelante serían pobladas con mayor densidad por los europeos; al contrario, las sociedades ubicadas al sur del Orinoco tuvieron más posibilidades de vivir sin contacto debido, en parte, a la mayor inaccesibilidad de su hábitat. Sin embargo, sostenemos también que sus prácticas religiosas pasaron más desapercibidas ante la mirada de los evangelizadores europeos al no signarlas como evidentemente "idolátricas", como sí las primeras. Asimismo, tales diferencias permiten demostrar en qué sentido las concepciones visuales de estos grupos humanos supusieron un factor importante que condicionaría las políticas colonizadoras y evangelizadoras de los primeros europeos llegados a esas tierras: ante la presencia de estatuillas de arcilla -llamadas por los colonos "ídolos"- y otros objetos que remitían de forma explícita a un uso ceremonial, se condenarían estas sociedades como idolátricas y heréticas. Por el contrario, las poblaciones con una cultura visual más abstracta, imbricada en objetos utilitarios y con menos símbolos figurativos, se considerarían carentes de "idolatría" y por tanto tendrían mayores posibilidades de sobrevivir el proceso colonizador.

\section{LOS HORIZONTES ICONOGRÁFICOS EN LA CUENCA DEL ORINOCO: DIFERENCIAS ENTRE NORTE Y SUR}

En el presente estudio, el uso que damos al concepto de horizonte iconográfico no ha de confundirse con el de horizonte, acuñado en la arqueología en Venezuela por Rouse \& Cruxent (tomado de Willey 1945) para determinar las "instancias según las cuales un estilo (sobre todo de cerámica) parece dar inicio a una cultura similar en otra área, y ésta da inicio a su vez a una tercera cultura en otra área, etc." (Rouse \& Cruxent 1963: 23). ${ }^{1}$ Aquí no tomamos el sentido de horizonte como una difusión lineal de influencias de una cultura a otra. No podemos determinar aún qué cultura dio inicio a uno u otro tipo de iconografía; solo observamos que estas se expandieron en el tiempo y el espacio, cubrieron regiones y culturas específicas y también se mezclaron entre estilos distintos.

Por otra parte, cabe señalar que el concepto iconografía es tomado de la historia del arte (Panofsky 1989, 2006) y de su etimología griega, sikẃv (eikon), según la 
cual el ícono se define como la imagen de algo que, en este caso, no necesariamente tiene que guardar relación con lo tangible o visible y que, por tanto, también puede referir a un elemento conceptual o espiritual, en fin, a una idea (ver Panofsky 1989). De esta manera, por iconografía podemos entender a su vez un tipo de imagen figurativa que mimetiza hasta cierto punto una forma presente en el mundo tangible, así como formas completamente abstractas -figuraciones geométricas- que simbolizan más bien ideas o conceptos que remiten a un plano metafísico o espiritual, que surgen por ejemplo de las visiones chamánicas de las sociedades amazónicas. Así, hemos identificado diversos tipos de horizontes iconográficos: algunos más figurativos, que conciben en su imaginario formas y efigies antropomorfas y zoomorfas; otros en cambio más geométrico-abstractos, en los que reconocemos algunas figuraciones antropomorfas o zoomorfas inmersas por completo en complejos entramados de volutas, líneas y figuras geométricas que abstraen su relación con su referente objetual-tangible y que se encuentran siempre plasmadas en objetos que cargan alguna funcionalidad.

A partir de estas premisas, sostenemos que las regiones en estudio, correspondientes a grandes rasgos al norte y al sur de Venezuela (con el río Orinoco como gran área de relación), expresan dos formas generales de concebir visualmente el mundo:

La primera -identificada en las sociedades del norte- utilizó una imaginería votiva más figurativa, en la que los seres sobrenaturales eran representados a través de formas zoo y antropomorfas; eso sí, siempre de manera muy estilizada o abstracta, nunca siguiendo una voluntad de representación del todo miméticonaturalista. Sugerimos que, antes de la Colonia, en estas regiones existieron algunos tipos de prácticas religiosas que hacían uso de imágenes concebidas bajo formas de estatuillas cuya funcionalidad principal era la de representar al ícono votivo (figs. 2 y 3 ).

La segunda -perteneciente a las formas del surdestaca por poseer menos representaciones figurativas en su cultura material. Asimismo, las figuraciones zoo y antropomorfas que pudiéramos hallar en estas regiones forman siempre parte del diseño; se encuentran imbricadas en un objeto que cumple alguna función, como una vasija o una flauta (figs. 4 y 5). Por tanto, en las sociedades al sur del Orinoco se optaría por una manifestación visual más abstracta y carente de objetos aislados de culto como estatuillas o efigies.

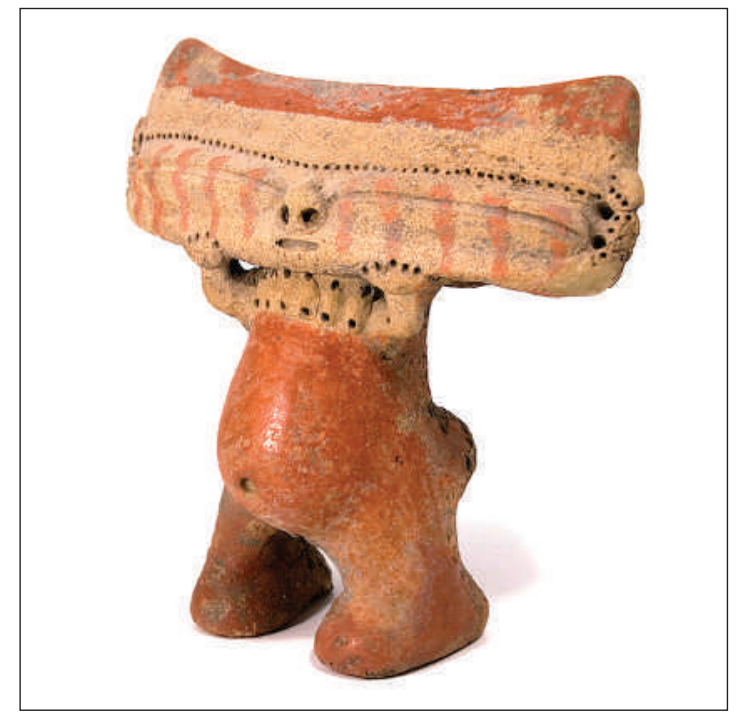

Figura 2. Estatuilla femenina. Arcilla, $17 \mathrm{~cm}$ de altura. ¿Estado Aragua o Carabobo? Estilo Valencioide, aprox. 1200 DC. Colección Kistermann, Aquisgrán (fotografía de la autora). Figure 2. Female statuette. Clay, $17 \mathrm{~cm}$ high. State of Aragua or State of Carabobo? Valencioid style, approx. 1200 DC. Kistermann Collection, Aachen (photo by the author).

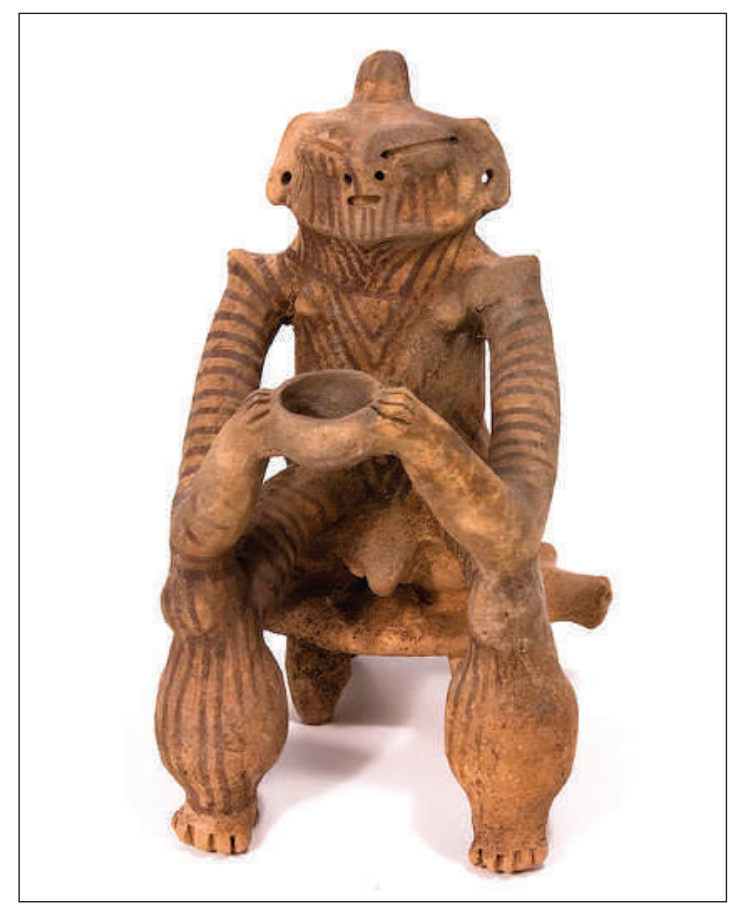

Figura 3. Estatuilla chamánica u "oferente". Arcilla, $40 \mathrm{~cm}$ de altura, Estado Trujillo. Tradición ¿Mirinday? Colección Kistermann, Aquisgrán (fotografía de la autora). Figure 3. Shamanic statuette or "offering". Clay, $40 \mathrm{~cm}$ high, State of Trujillo. Mirinday tradition? Kistermann Collection, Aachen (photo by the author). 


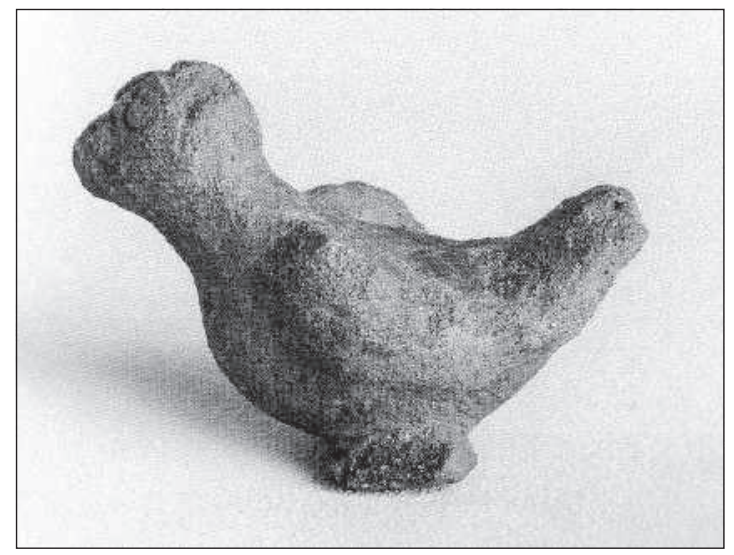

Figura 4. Flauta ornitomorfa. Arcilla ocre claro, estilo Nericagua; Ventuari Medio, Estado Amazonas, 600/800-1500 DC. Colección Museo de Ciencias de Caracas (fotografía de Carlos Germán Rojas). Figure 4. Ornitomorphic flute. Light ochre clay, Nericagua style; Middle Ventuari, State of Amazonas, 600/800-1500 AD. Museo de Ciencias de Caracas Collection (photo by Carlos Germán Rojas).

El principal motivo que nos llevó a estudiar estos horizontes iconográficos es que ellos, así como las prácticas ceremoniales asociadas, parecen existir de forma independiente a los estilos de alfarería, así como a una cultura o grupo lingüístico específico. De la misma manera, no solo evidenciamos concomitancias entre las prácticas de culto de sociedades que en apariencia no tienen relación alguna, sino que encontramos estilos y prácticas culturales muy distintas en sociedades que, por lo contrario, sí parecen tener orígenes étnicos comunes. En consecuencia, los estilos y las formas de culto pertenecientes a culturas de una misma familia lingüística pueden variar considerablemente. Por ejemplo, los Wayúu que hoy habitan en la península de la Guajira (de afiliación lingüística Arawak) casi no comparten rasgos estilísticos con los Wakúenai (también Arawak) del Amazonas. En este sentido, aquellos pueblos prehispánicos asociados a ramificaciones Arawak o Caribe en el septentrión venezolano llegaron a producir de manera prolífica estatuillas de cerámica, pero los miembros de los mismos grupos lingüísticos del Amazonas (del Alto Orinoco) y la Guayana no habría desarrollado este tipo de costumbres.

A partir de la lectura antropológica e histórica amerindia, queda claro que los cambios estilísticos y el desuso o suplantación de ciertas prácticas por otras forman parte de un proceso natural y orgánico en el

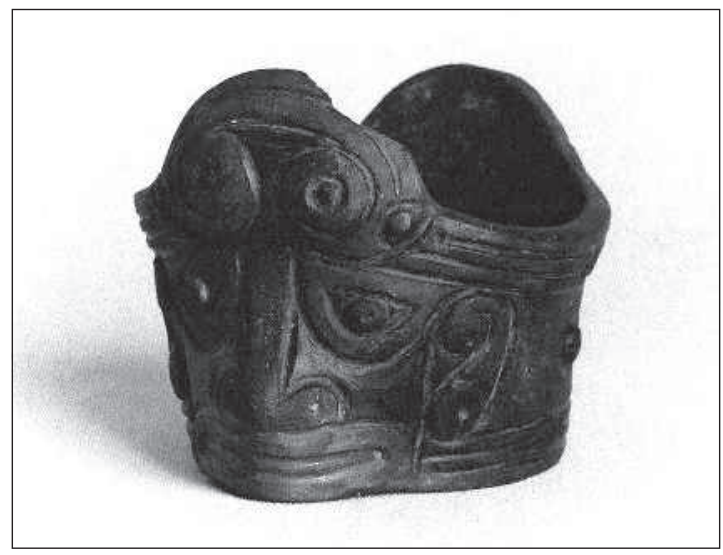

Figura 5. Vasija-efigie con tocado círculos concéntricos. Arcilla siena, posible engobe marrón oscuro. Serie Barrancoide, 1000 AC-600 DC, Barrancas (cercanías), Estado Monagas. Fundación Museo de Ciencias de Caracas (fotografía de Carlos Germán Rojas). Figure 5. Effigy-vessel wearing a headdress with concentric circles. Siena clay, possibly with dark brown slipware. Barrancoid series, 1000 BC-600 AD, Barrancas (proximities), State of Monagas. Fundación Museo de Ciencias de Caracas (photo by Carlos Germán Rojas).

devenir histórico de cada cultura. Asimismo, se ha comprobado que las sociedades que habitaron estos territorios amazónicos y caribeños intercambiaban numerosos rasgos culturales con otros grupos étnicos desde mucho antes de la Colonia (Gassón 2000, Heinen \& García Castro 2000, Biord-Castillo 2005). Durante el Período Prehispánico reconocemos una vertiginosa difusión, transmisión y apropiación de varios estilos, lo cual invalida las nociones rígidas y simplistas que se han asumido con frecuencia sobre el supuesto aislamiento y estatismo de estas sociedades. Tampoco podemos obviar el cambio radical generado por el contacto con el europeo, que produjo un quiebre profundo y modificó el mapa cultural de estas regiones en un lapso temporal relativamente corto.

A pesar de las dificultades metodológicas enfrentadas al estudiar la cultura material prehispánica, hemos identificado ciertas constantes espacio-temporales con la del presente. Por ejemplo, tenemos constancia de que en la actualidad continúan ciertas costumbres funerarias (como el doble funeral), la pintura y decoración corporal, el trabajo con la cestería y la alfarería, etc. No obstante, entre el vasto repertorio visual que nos ha llegado del pasado, un elemento que puede considerarse extinto entre las prácticas culturales del presente amerindio son las estatuillas de cerámica, que estudiaremos a continuación. 


\section{Horizontes iconográficos del septentrión venezolano: iconografía chamánica e iconografía femenina}

Una vez adentrados en aquellos horizontes iconográficos del Período Prehispánico que concebían estatuillas votivas, identificamos dos tipologías principales, que podrían indicar dos tipos de culto diferentes, aunque se hallan simultáneamente en el mismo período y lugar estilístico, así como dispersas en momentos y regiones muy distantes. Estas se distinguen formalmente del siguiente modo: la primera corresponde a estatuillas de género femenino en las que destacan ciertos elementos físicos como los muslos, senos y/o también el embarazo. Asimismo, ejercen algún tipo de gesto ritual (tocan algún instrumento, llevan una máscara, etc.) y muestran ornamentos corporales particulares (como pinturas, collares, penachos y deformaciones corporales). La segunda corresponde a una representación que llamaremos chamánica o de transformación, ya que en ella se evidencian gestos y atuendos implementados en rituales o ceremonias realizadas por los guías o jefes espirituales de diversas etnias indígenas, descritas tanto en período Colonial como en la actualidad. Se observa así que los contextos culturales que hacían uso de estas estatuillas se expandieron por toda la región septentrional de Venezuela, hasta llegar a las Antillas Mayores e islas adyacentes a la costa venezolana. Dicha recurrencia iconográfica se reconoce en diversos estilos alfareros que indican una asociación con grupos étnicos y familias lingüísticas distintas.

Los potenciales simbolismos de la cultura material amerindia son tan complejos que desde la perspectiva occidental ha sido difícil elaborar una idea concisa sobre la identidad y el significado de sus objetos de culto. La evidencia arqueológica se ha limitado a ubicar dichas piezas en contextos ceremoniales y determinar, hasta cierto punto, algunos usos prácticos que se les daba - por ejemplo, si eran utilizadas en los rituales, acompañaban a los difuntos en contextos funerarios, etc.-Sin embargo, se hace difícil establecer con exactitud qué concepción tenían los habitantes de estas regiones sobre sus estatuillas votivas en el período prehispánico.

Como venimos señalando, las estatuillas femeninas podrían aludir a simbolismos y rituales asociados a la fertilidad, aunque su variedad sugiere significados mucho más complejos; por otro lado, también podrían verter luz sobre posibles rituales en los que se utilizaban máscaras (muchas de las figuras parecen llevar una) y tocaban diversos instrumentos musicales. Esta iconografía pareció expandirse durante un largo período de tiempo por la costa central de Venezuela, a lo largo de los llanos occidentales (sobre todo en Quíbor), hasta las estribaciones andinas. Su gran proliferación regional alcanzó igualmente una variedad estilística y una maestría técnica. En este sentido, adquirió mayor fuerza y recibió un tratamiento estilístico particular en el lago de Valencia (fig. 1), así como en su respectiva esfera de interacción comercial y cultural (las islas adyacentes a la costa y la región litoral norcentral).

Sin embargo, también hay evidencias de que las estatuillas femeninas existieron en las regiones del bajo Orinoco, aunque en menor medida que en la región norcentral. En efecto, la serie alfarera Barrancoide -una de las más antiguas en Venezuela (1000 AC a 600 DC)llegó a elaborar este tipo de imágenes femeninas, aunque hasta ahora se haya conservado tan solo un ejemplar (fig. 6), lo que hace de este caso un verdadero enigma. Las tradiciones visuales del Orinoco (que incluyen las series Barrancoide y Salaloide) llegaron a desarrollar además un estilo que despliega un amplio y muy complejo repertorio de figuras zoo y antropomorfas. No obstante, estas piezas no son consideradas aquí propiamente como ídolos, puesto que se encuentran siempre en vasijas y urnas funerarias (típicas son las tapas de urnas funerarias antropomorfas, así como los apéndices de vasijas con figuras de animales o humanos; véase fig. 4). Por último, advertimos que a pesar de que la tradición Salaloide precedió a la cultura taína desarrollada en las Antillas (Rouse 1989), no parece haber transmitido el tipo de culto en el que se utilizaban estatuillas sentadas sobre dúhos, que entre los taínos se convertirían en los cemíes.

Lo anterior nos conduce a la segunda iconografía de estatuillas que se conoce comúnmente como los chamanes sentados sobre dúhos u oferentes (que pueden ser tanto figuras femeninas como masculinas): estas asumen una postura que se ha interpretado como en estado de trance y se caracterizan por la presencia de ojos cerrados, lagrimeo, dientes expuestos, columna vertebral, costillas remarcadas y órgano sexual erecto. Se expande desde la región andina y su piedemonte hasta las Antillas (con los cemíes taínos). Encontramos así una pieza "chamánica" del temprano estilo Santa Ana (1000 AC-300 DC) (fig.7) y luego el más tardío estilo Mirinday (1000-1600 DC) (fig. 2). Aunque en la región norcentral existen pocos ejemplares de esta 


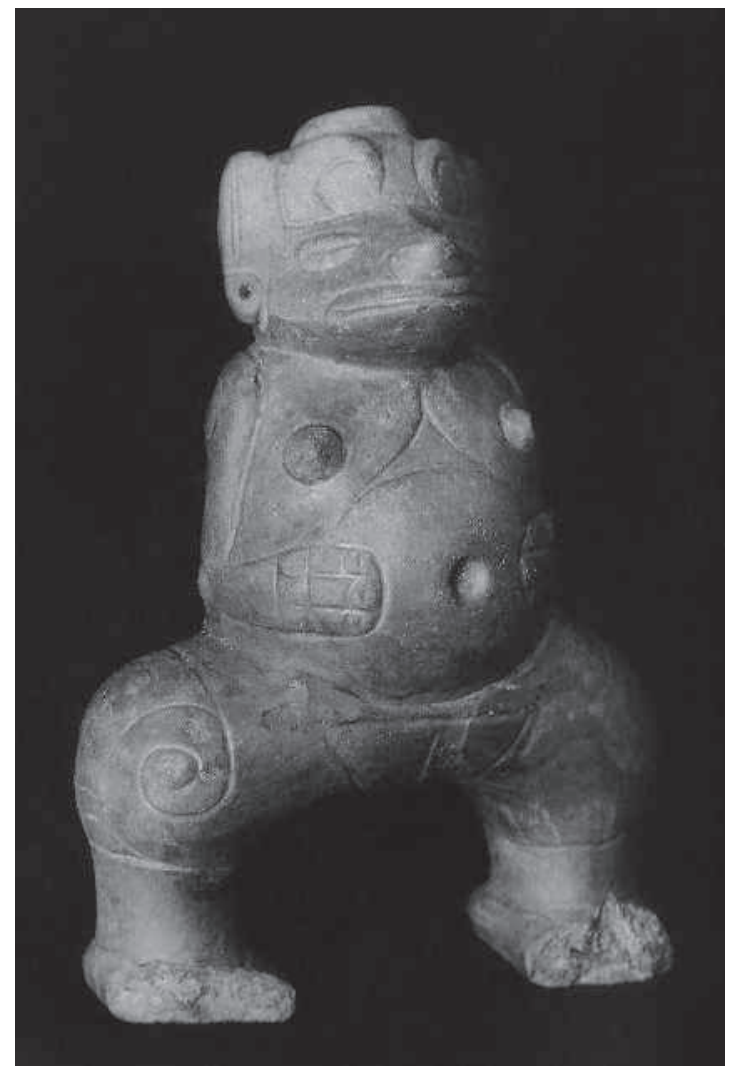

Figura 6. Estatuilla femenina con piernas en forma de arco. Arcilla marrón, engobe rojo; 25,5 x 18,3 x 11,3 cm. Barrancas (cercanías), Estado Monagas. Serie Barrancoide, Los Barrancos, 1000 AC-600 DC. Fundación Museo de Ciencias, Caracas (fotografía de Carlos Germán Rojas). Figure 6. Female statuette with arch-shaped legs. Siena clay, possibly with dark brown slipware. Brown clay, red slipware; $25.5 \times 18.3 \times 11.3 \mathrm{~cm}$. Barrancas (proximities), State of Monagas. Barrancoid series, Los Barrancos, 1000 BC-600 AD. Fundación Museo de Ciencias, Caracas (photo by Carlos Germán Rojas).

iconografía, curiosamente no fue tan popular allí, donde predominó un tipo de culto que utilizaba las estatuillas femeninas. Tampoco la observamos en la Guayana o en el Amazonas, lugares que por lo general carecieron de una imaginería de estatuillas de cerámica como la observable en el norte.

Un elemento predominante en ambos tipos de figuración antropomorfa son los atuendos corporales que culturizan la figura y la diferencian del estado "natural" o "salvaje", uniéndolos en cambio al universo trascendental y social al cual pertenecen los ancestros, divinidades y animales míticos. ${ }^{2}$ Cabe subrayar que en el mundo amerindio se han practicado cultos que responden a distintas formas de relación con el mundo

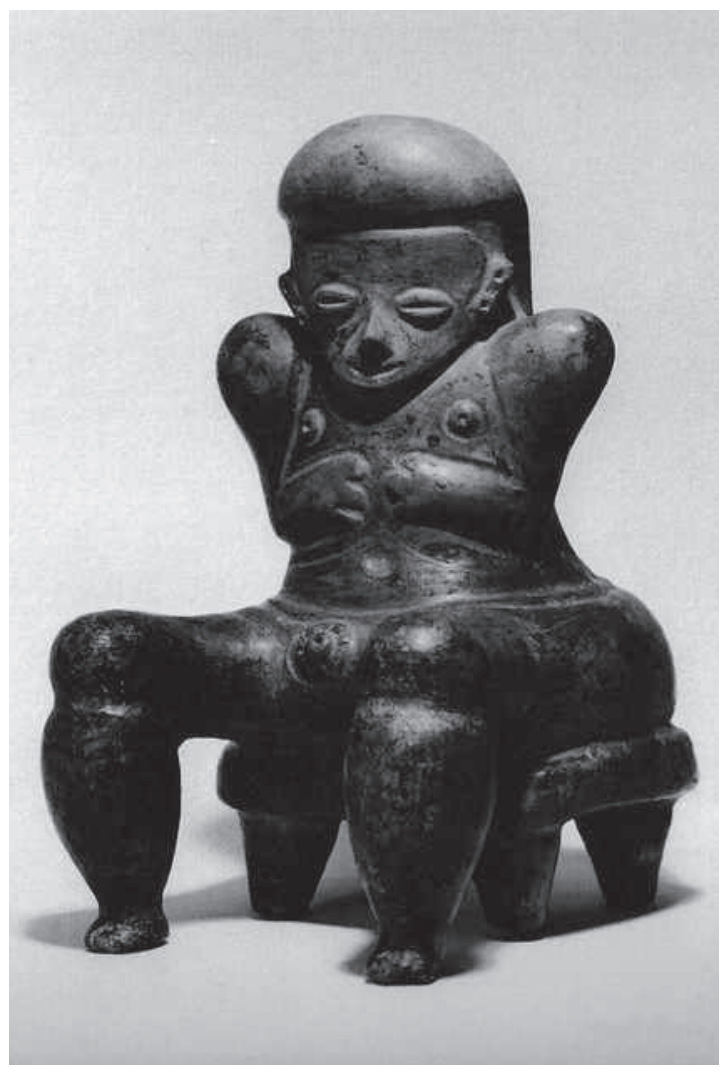

Figura 7. Hombre sobre dúho. Arcilla marrón, engobe blanco, pintura marrón oscuro. Carache, cueva de Santo Domingo, Estado Trujillo. Estilo Santa Ana (Período II, 1000 AC-300 DC). Fundación Museo de Ciencias, Caracas (fotografía de Carlos Germán Rojas). Figure 7. Man sitting on a dúho. Brown clay, white slipware, dark brown paint. Carache, Santo Domingo cave, State of Trujillo. Santa Ana style (Period II, 1000 DC-300 AD). Fundación Museo de Ciencias, Caracas (photo by Carlos Germán Rojas).

sagrado y natural. Estos tipos de prácticas religiosas y concepciones simbólicas no parecen estar sujetos a una sociedad o tradición específicas, sino que corresponden más bien a las transmisiones de rasgos culturales que pudieron haberse propagado a través de los circuitos de comunicación interétnicos, particularmente intensos en la región noroccidental y norcentral de Venezuela. De este modo, la expansión iconográfica de las estatuillas pudo producirse en grupos étnicos distintos, hecho que indicaría la prevalencia de una concepción de prácticas ceremoniales y un imaginario cosmogónico expandido a nivel intercultural.

Otro elemento común entre ambas imaginerías es su utilización tanto para el culto colectivo como para 
la veneración íntima y cotidiana. El reducido tamaño y la producción masificada de algunas de estas estatuillas sugiere que eran manipuladas por un amplio rango de la población, que las podía movilizar de un lado a otro sin dificultad. El mismo hecho evoca la existencia de una práctica popularizada en diversos momentos históricos, mostrando así ricas "transformaciones" en su concepción formal y en sus usos. Sabemos también que las estatuillas antropomorfas con frecuencia tenían alguna funcionalidad; por ejemplo, algunas eran sonajeros, lo cual indica que el objeto también debía ser tocado, bailado, en fin, utilizado. Sin embargo, estas funciones utilitarias estarían siempre enmarcadas en un contexto ritual.

El estilo abstracto que adoptan las estatuillas antropomorfas de cerámica responde en este sentido a la necesidad de adaptar el mundo real y tangible a un ideal trascendental, así como a la concepción mítica sobre el mundo. El estilo abstracto demuestra una voluntad por hacer visible algo que en principio no lo es; algo que, si bien puede sugerir en ciertos momentos alguna analogía con la naturaleza, siempre se manifestará a través de simbolismos crípticos que refieren al espacio sobrenatural y que solo algunos podrán revelar de manera sensible.

\section{Horizontes iconográficos al sur del Orinoco: parafernalia ritual sin estatuillas}

Los horizontes iconográficos del Amazonas y la Guayana venezolana muestran características particulares que se alejan de la imaginería figurativa que concibe, por ejemplo, estatuillas antropomorfas. Aquí encontramos una iconografía mucho más abstracta, imbricada siempre en objetos que pueden ser tanto utilitarios como rituales. Abundan las cestas decoradas con innumerables tipologías de patrones visuales, penachos de plumas y pieles de mono, diversos patrones de pintura corporal y atuendos, pintura rupestre, así como otras formas simbólicas talladas o esculpidas en diversos soportes. Asimismo, abunda la imaginería mítica que se transmite oralmente y que concede a todo objeto creado por el hombre un particular significado mítico y trascendental. La ontología amazónica, en términos de Viveiros de Castro (2010), se ve expresada en todos los objetos.

No obstante, si bien cabe la posibilidad de que los pueblos del sur elaboraran algunas estatuillas en madera u otros materiales perecederos, no parecen haber forjado un sólido imaginario simbólico a través de materiales "duraderos" o no orgánicos (como la arcilla o la piedra) con la misma fuerza o proliferación evidenciada en el norte -al menos no se tiene constancia arqueológica de ello-. Sin duda, los horizontes iconográficos que aquí existieron y aún existen son diferentes de los analizados más arriba.

En consonancia con lo dicho, Taylor (2011: 42) ha remarcado estas diferencias iconográficas entre las sociedades amazónicas y las culturas alfareras andinas y caribeñas. Según la autora, las sociedades amazónicas contemporáneas se caracterizan por mantener una sorprendente sobriedad visual en su cultura material: se trata de un mundo muy "limitado" en objetos que, además, carecen cuantitativamente de las decoraciones visuales observables en la alfarería prehispánica. Hoy en día sobreviven solo algunos casos excepcionales Taylor expone el de los Quichua Canelos de Ecuador o los Waùja del Xingú- en los que se ha mantenido una continuidad directa con las culturas alfareras prehispánicas, ya que aún elaboran una alfarería polícroma con una compleja simbología visual. También tenemos en cuenta las culturas alfareras en Santarém o Marajó, cuya alfarería muestra una compleja "iconicidad". Sin embargo, en líneas generales las sociedades amazónicas (al menos entre los ríos Amazonas y Orinoco) se han especializado más bien en la producción de objetos "efímeros" (desechables, perecederos) en que se plasman intrincadas decoraciones abstractas basadas en meandros y figuraciones geométricas. Estos objetos son altamente funcionales y requieren de una gran habilidad técnica para su confección, pero tampoco carecen de valor simbólico, puesto que se convierten en verdaderas "prolongaciones" del cuerpo de quien los usa (Taylor 2011: 42).

En este régimen visual, los símbolos trascendentales son plasmados de manera mucho más abstracta que en las culturas desarrolladas en el septentrión venezolano. Podrían pertenecer a aquella ontología amazónica de la que habla Viveiros de Castro (2002), cuyo mundo material se ve impregnado completamente de un significado mítico y por tanto sagrado. En estos casos, al no ejercerse ningún culto a ninguna deidad o entidad sagrada particular -sino que todo posee un "alma" o "dueño"-, la imaginería visual parece refugiarse tan solo en los objetos y los cuerpos humanos. Ahora bien, en aquellos objetos que sí obtienen un tratamiento decorativo particular podemos reconocer iconografías abstractas 


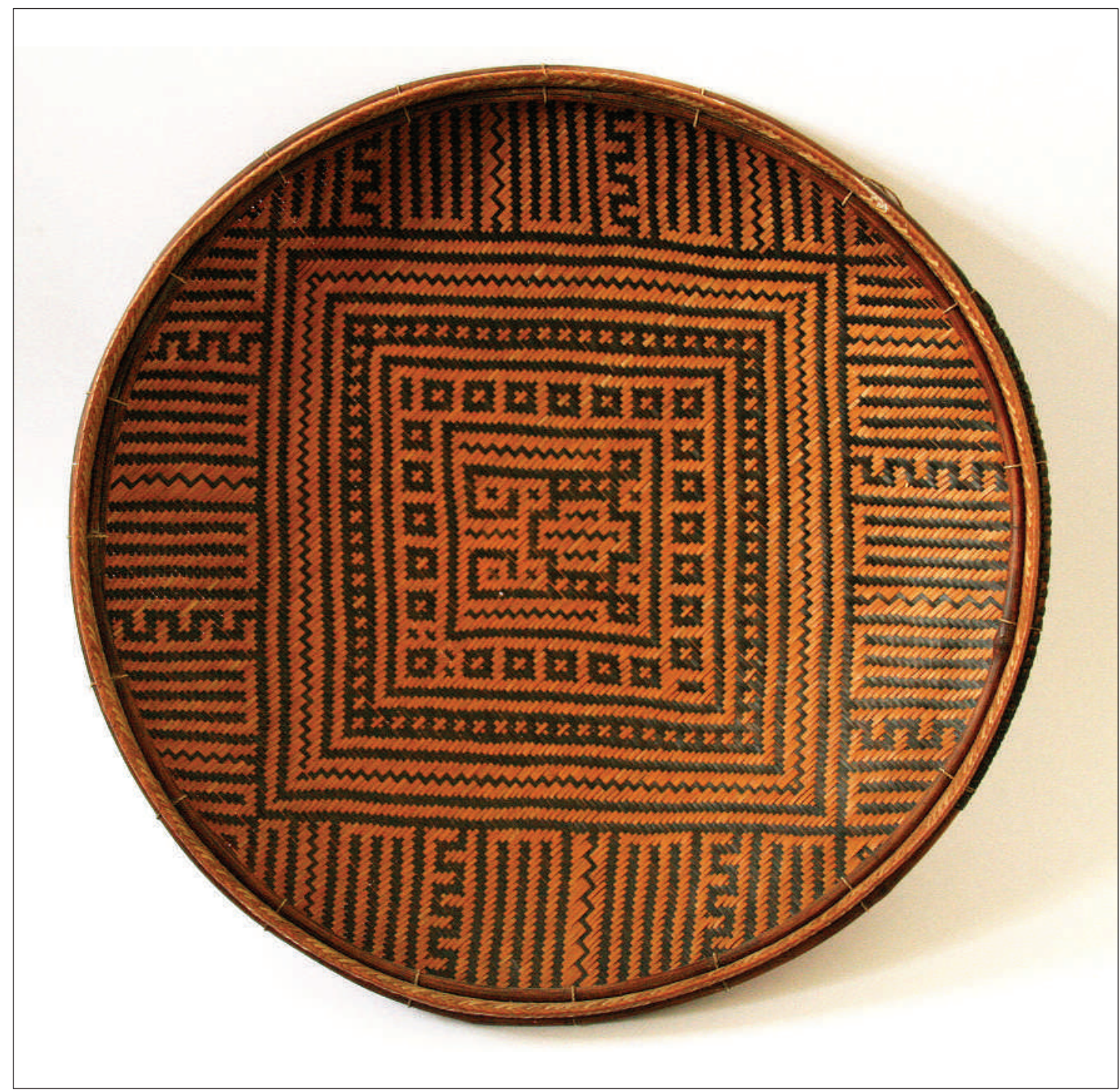

Figura 8. Cesta Ye’kuana con imagen doble del mono mítico Iadaakadu, Estado Amazonas. Colección Etnográfica ICAs, Fundación La Salle, Caracas (fotografía de la autora). Figure 8. Ye'kuana basket with the double image of the mythical monkey Iadaakadu, State of Amazonas. ICAS Ethnographic Collection, Fundación La Salle, Caracas (photo by the author).

y geométricas de símbolos y entidades míticas, como es el caso de la cestería Ye'kuana, de la rama lingüística Caribe (fig. 8).

Pensamos que el tipo de manifestaciones icónicas en época precolombina debió ser similar al que se encuentra hoy entre los pueblos indígenas. Aunque debemos añadir que, debido al contacto con el mundo criollo, la proliferación de vasijas de cerámica, pintura rupestre y la existencia de prácticas funerarias se ha ido perdiendo.

\section{AL ACECHO DE LA "IDOLATRÍA": INTERPRETACIONES DE LOS HORIZONTES ICONOGRÁFICOS A PARTIR DE LA COLONIA}

A raíz de las diferencias entre horizontes iconográficos, decidimos volcar nuestra atención hacia las fuentes históricas y etnográficas que van desde Período Colonial hasta entrado el siglo $\mathrm{xx}$, para determinar hasta qué punto existen referencias sobre distintos tipos de cultos 
e imaginarios visuales entre las culturas que los primeros europeos en llegar a estos territorios exploraron y describieron. En estas fuentes esperamos encontrar posibles alusiones a la existencia de "idolatría" $\mathrm{o}$ descripciones de la cultura material entre las comunidades indígenas que entraron en contacto con el mundo europeo. La amplitud temporal considerada en la revisión de los documentos se debe a que, al sur del Orinoco, el contacto con el mundo europeizado fue mucho más lento que en otras regiones americanas. De ahí que encontremos, incluso avanzado el siglo XIX, primeras menciones sobre grupos indígenas de la zona.

El interés que supone acudir a las fuentes históricas es que en ellas se puede identificar una diferenciación entre las regiones ubicadas al norte y al sur del Orinoco. En estos casos no se hablaba de horizontes iconográficos o de ontologías visuales, sino que las culturas se distinguían por ser o no "idolátricas" y por poseer o no lo que desde la perspectiva europea (y principalmente cristiana) se distinguía como "religión”, definido por Gumilla (1963) como la existencia de templo, sacerdote y rito. Esto es importante porque, como es de suponer, la idea que servía a los europeos para distinguir la presencia de religión e idolatría en una cultura indígena dependía del hecho de que pudieran identificarlas como tales. Y, en efecto, en las regiones septentrionales (noroccidente y la costa central, sobre todo) reconocieron a las estatuillas votivas como ídolos, mientras que en el sur se asombraron de su ausencia.

Como ha aseverado Belting (2005: 34), la palabra "ídolo" contiene una connotación negativa desde las primeras discusiones sobre su significado en la Grecia Antigua y a lo largo del Cristianismo. Designaba una imagen falsa y engañosa, puesto que no admitía, según esta postura, la verdadera trascendencia e inmaterialidad de lo divino. Esta acepción del concepto nos ayuda a entender la perspectiva con que los primeros europeos describieron las estatuillas votivas de las culturas indígenas. Al interpretarlos como ídolos y asociarlos por tanto a un tipo de representación de lo divino, aquellos objetos serían los primeros en sucumbir al proceso evangelizador colonial y ser condenados a la proscripción. Otra suerte correría otro tipo de imaginería religiosa que, debido a las características que ya se han señalado, sería irreconocible como tal.

Cabe señalar que cuando los europeos llegaron muchas tradiciones alfareras habían dejado de existir en el continente, en específico, en los territorios que hoy conforman Venezuela. Aquellas culturas que habían elaborado estatuillas o complejas iconografías antropomorfas y zoomorfas en la región del Orinoco, como el estilo Barrancas o Saladero, habían desaparecido hace centenares de años o milenios. En cambio, las culturas que para aquel entonces mantenían este tipo de imaginerías se ubicaban preponderantemente en los Andes (la tradición Mirinday), la Esfera de Interacción Valencioide y el noroccidente venezolano (la tradición Tierroide y Dabajuroide).

Recordemos también que las poblaciones que vivían en el septentrión venezolano (sobre todo el noroccidente) se vieron reducidas en pocos años tras el contacto con doctrinas y encomiendas. Aquellos pueblos que no fueron diezmados por completo terminaron por hibridarse con la población criolla, convirtiéndose en un nuevo constructo cultural, mestizo y cristiano. Los colonos reubicaron de este modo muchos pueblos en regiones que les eran extrañas y entremezclaron diversas comunidades sin ningún tipo de criterio étnico ni cultural (Marcano 1971: 168).

\section{Crónicas y primeras etnografías sobre el norte}

En líneas generales, se ha explicado la desaparición de la imaginería antropomorfa y zoomorfa -así como su contexto ceremonial- por la severa persecución, prohibición y destrucción de los objetos votivos que cayeron en manos de los conquistadores y evangelizadores cristianos a partir de la Colonia. Esto es comprobable en los textos de Marcano (1971: 112), quien resumió diversas acciones ejercidas por los primeros colonos en Venezuela para destruir las costumbres indígenas, en las que veían, por ejemplo, actos de canibalismo. Asimismo, Alfredo Jahn (1973: 126) describió la destrucción del ajuar cerámico y de piedra de los pueblos andinos por la "persecución que les hacían los misioneros, quienes con su estrecho criterio fanático, veían objetos de idolatría en toda obra de este género". Existen por consiguiente varias fuentes que evidencian la destrucción pública de ídolos durante la Colonia, lo cual marca definitivamente un antes y un después entre el período anterior y el posterior a la conquista española. ${ }^{4}$

Asimismo, subrayamos la considerable reducción demográfica de las poblaciones indígenas, que han ido desapareciendo o hibridándose progresivamente desde el momento de contacto hasta la actualidad. Esta 
diseminación afectó, sobre todo, las regiones del litoral y el occidente de Venezuela (las más pobladas por los colonizadores). Así lo leemos en los estudios del antropólogo Whitehead (1988: 36) que indican el descenso de la población caribe en estos territorios a más de un $50 \%$ entre el siglo XVIr y el período de independencia de Venezuela (1810). Sin embargo, el proceso de diseminación y reducción de las poblaciones indígenas continuaría hasta avanzado el siglo xx, lo cual vemos reflejado en los estudios de Alfredo Jahn (1973), quien para los años veinte denunciaba aún la vertiginosa desaparición de diversas etnias. ${ }^{5}$ No obstante, teniendo en cuenta la irrefutable violencia con la que se devastó, no solo demográfica sino también culturalmente el horizonte social amerindio, debemos considerar que otras posibles causas de su extinción fueron las guerras y los conflictos internos entre los propios pueblos, frecuentes desde antes de la Colonia. De hecho, constante mención en todos los relatos y crónicas de los siglos XVI a XVIII son las numerosas y persistentes persecuciones, matanzas y guerras entre las diversas sociedades, que como consecuencia diezmaron poblaciones enteras (Federmann 1916).

A pesar de esto, en las primeras crónicas sobre el proceso colonizador en Venezuela leemos que el noroccidente estuvo densamente poblado por diversos grupos étnicos. Estos fueron asociados a distintas familias lingüísticas (Arawak, Caribe, Warao, Saliva) que hoy en día ya no existen en su mayoría como grupos independientes (en estas regiones), puesto que se han entremezclado con la población mestiza. Federmann (1916) enumeró, por ejemplo, en sus crónicas sobre el viaje desde la ciudad de Coro hasta los llanos occidentales (1530-1531), numerosos "reinos" indígenas que hablaban distintas lenguas y que se diferenciaban fisionómicamente. ${ }^{6}$ Cabe destacar que Federmann no dominó por completo el área norcentral y occidental de Venezuela; al parecer, el valle de Quíbor continuó siendo poblado por distintas comunidades independientes hasta la sucesiva llegada de los españoles, quienes las reunieron en encomiendas y doctrinas. A pesar de deber renunciar a sus prácticas religiosas tradicionales tras la conquista europea, estos grupos indígenas lograron mantener algunas costumbres culturales y comerciales hasta entrado el siglo xx (Arvelo 2000).

Nos desplazamos así a uno de los escritos que hace mención explícita de las prácticas idolátricas, perteneciente al fraile Pedro de Aguado. Este describió a finales del siglo XVI algunas costumbres rituales y funerarias de las poblaciones al sur de Carora, en el actual Estado Lara: "La gente de esta provincia de Cuicas es, como he dicho, gente que anda desnuda, crecida y muy lucida y bien agestada, es idólatra, tienen o usan de algunas figuras en que adoran, que llaman los españoles tunjos" (Aguado 1915: 265).

Las figuras mencionadas por el historiador podrían corresponder a uno de los numerosos estilos alfareros que constituyen el complejo ajuar arqueológico del valle de Quíbor, donde varias culturas alfareras que comenzaron a asentarse aproximadamente a partir del $300 \mathrm{AC},{ }^{7}$ hasta la llegada de los colonizadores. El cronista no dedicó mayor atención a la descripción de la vida y las usanzas de las diversas poblaciones aborígenes, puesto que sus textos se limitan más bien a relatar las luchas, guerras y diversos obstáculos que debieron afrontar los conquistadores en su encuentro con los pueblos "bárbaros". Sin embargo, una vez más -y en parte debido al interés táctico militar que esto suponía- menciona la existencia de alianzas políticas, comerciales, matrimoniales y rituales entre distintas sociedades indígenas (Aguado 1915: 167). También hemos hallado otros breves comentarios sobre templos o lugares de culto en los que se llevaban a cabo estas prácticas idolátricas ubicadas, por ejemplo, en los llanos (Aguado 1915: 134).

Continuando nuestra búsqueda de indicios de idolatría, encontramos en el septentrión venezolano algunas descripciones sobre las prácticas de culto y los templos hechas por el prócer Francisco Javier Yanes en el temprano siglo xIx y recopiladas años más tarde por Gaspar Marcano. Reproducimos aquíla interpretación del historiador sobre los posibles cultos practicados por los indios Caracas, en que muestra cómo se asociaron con las estatuillas femeninas de la serie Valencioide:

La religión de los indios Caracas era una ingenua idolatría, muy en harmonía con su simplicidad. Adoraban las montañas, las plantas, los animales, las piedras (notas inéditas de F.J. Yanes). No sabemos si conocían una divinidad superior. El sexo único de los ídolos parece conformarse al principio de una adoración común, como la tierra, la luna, la agricultura. Lo cierto es que creían en un espíritu maligno a quien hacían sacrificios o más bien ofrendas, porque ellos estaban muy lejos de la cruel idolatría de los aztecas y otros pueblos precolombinos. Sus altares eran las chozas, la cima de un peñasco, la orilla de un arroyo y hasta los huecos de los árboles. Colocaban allí sus ídolos a quienes dirigían sus plegarias, al son de los botutos (Marcano 1971: 109-110). 
A pesar del carácter interpretativo de esta descripción, notamos que aun para la llegada de los colonos se encontraban estatuillas femeninas de cerámica con las que los indígenas practicaban sus cultos. Un aporte interesante de las descripciones de Marcano es la asociación que hace de las prácticas religiosas de los indios Caracas con los ídolos femeninos, que - por las fotografías y las descripciones que aportó- pertenecen a las estatuillas de la serie Valencioide. Al no poder asegurar, sin embargo, que estas piezas correspondieran efectivamente a dichos pueblos, ${ }^{8}$ nos preguntamos entonces: ¿de qué ídolos se trataba?, ¿los elaboraban ellos mismos o se trataba de estatuillas "encontradas" y "reutilizadas"?

\section{Crónicas y etnografías sobre el Orinoco}

Destaca que tanto en las crónicas de los primeros colonos como de los sucesivos exploradores y misioneros europeos casi no se mencione la existencia de prácticas idolátricas entre las culturas de estas regiones. Tras una larga búsqueda entre las fuentes históricas coloniales, podemos verificar que nos han llegado algunos comentarios sobre los poderes de los jefes y chamanes, así como sobre las "supersticiones" de los indígenas y los lugares en donde practicaban sus rituales. Sin embargo, resulta muy llamativo el hecho de que los documentos que describen algunas prácticas idolátricas entre los pueblos amerindios se refieren tan solo a las regiones septentrionales de Venezuela.

En cuanto a las primeras incursiones hacia el sur del Orinoco, uno de los primeros colonos que se adentraron en las profundidades de la Guayana fue Diego Ordaz, quien remontó el río en 1531 en búsqueda de El Dorado y estableció el primer contacto con los indígenas. La búsqueda de El Dorado sería la principal motivación que conduciría a los exploradores a estas tierras indómitas. Mas, tras los cuatro viajes frustrados de Walter Raleigh, entre finales del siglo xvi y principios del XVII, iría desmitificándose poco a poco la idea de que El Dorado se encontraba allí.

Tal como podemos leer en la historiografía de Gaspar Marcano, la Guayana fue un territorio difícil de dominar para los europeos; las expediciones en búsqueda de El Dorado (o con miras a colonizar el área) fracasaron debido a las duras condiciones climáticas y geográficas, así como a la violenta resistencia de los pueblos indígenas. Por otro lado, las congregaciones religiosas que lograron penetrar exitosamente estas regiones y reunir a las sociedades indígenas en encomiendas y misiones se centraron sobre todo en "colonizar las almas" (el bautizo y la doctrina), desatendiendo su estructura y organización social. Esto traería como consecuencia la progresiva desaparición de las comunidades reunidas por el yugo colonizador: "Los resultados de esos procedimientos fueron tales, que ni siquiera se llegó a establecer la religión cristiana en las soledades de la Guayana, y el número de los aborígenes disminuía día a día [...]. La civilización indígena de la Guayana, innegable por sí misma cuando sus habitantes poseían libertad, había desaparecido en el momento de su visita a las misiones" (Marcano 1971: 166-167).

En dicho sentido, la desorganización del proceso colonizador acarreó el progresivo debilitamiento de las estructuras sociales amerindias que se encontraron bajo su dominio. A su vez, tal como también se verifica en los escritos de Humboldt (1826), aquellas comunidades indígenas que ofrecieron resistencia a la imposición colonial o que se rehusaron a abrazar la doctrina cristiana fueron exterminadas.

Situándonos en las regiones meridionales de Venezuela, hemos consultado las crónicas del jesuita José Gumilla (1963), quien viajó por las inmediaciones del río Orinoco a inicios del siglo xvirI. En sus escritos detectamos la idea de que allí solo parecieron existir religiones paganas y rudimentarias. Esto se debía, argumentó el misionero, a que la idolatría presente en el norte había sido introducida por los imperios de Perú (por los "Incas y Moctezumas [aztecas]"). Según sus cálculos, estos pueblos lograron expandir sus dominios hasta las regiones andinas y noroccidentales de Venezuela, sin arribar al sur del Orinoco. Así, leemos cómo estos imperios andinos fueron sembrando los cultos idolátricos en aquellos pueblos dominados que originalmente eran "paganos":

\footnotetext{
los dos emperadores americanos [los Incas y Moctezumas] no tenían por suya la provincia nuevamente conquistada hasta que introducían en ella la idolatría; pero como les restaban muchas por conquistar, cuando fueron conquistados, en casi todas éstas no se hallaba idolatría, sino un mero paganismo muy tosco, si bien es verdad que con el trato y comercio de estos inmediatos a las Provincias conquistadas ya tenían sus ídolos; y a no haber llegado la luz del Evangelio, hubiera ido caminando la idolatría (Gumilla 1963: 192).
}

En su crónica, Gumilla describió aquellos rasgos culturales que para él resultaban más sobresalientes, como las prácticas religiosas de las diversas naciones 
indígenas con las que mantuvo contacto durante sus años de misionero en el Orinoco. Mencionó, entre otros grupos étnicos, a los Caribe, los Sáliva, los Achagua, los Otomacos, los Arawak, etc.; mas no llegó a describir en ningún caso la presencia de ídolos o la existencia de algún tipo de veneración de figuras o lugares de culto en particular. Columbró, en cambio, que estas prácticas solo se encontrarían entre las grandes civilizaciones de los Andes y en Centroamérica. A pesar de reconocer el culto a ciertos "demonios" (animales, espíritus), por lo general, Gumilla se gratificó en pensar que estos pueblos del Orinoco carecían de culto alguno, por lo que estaban a salvo de adorar al demonio (1963: 291). ${ }^{9}$

Sin duda, resulta sorprendente que también Pedro de Aguado mencionara una invasión peruana en el norte de Venezuela, la cual presuntamente habría implantado la idolatría entre los aborígenes del noroccidente venezolano:

El indio, el moro, el gentil, todas cuantas naciones ha habido en el mundo que ciegamente adoraban y tenían por dioses los simulacros y obras de sus manos y de naturaleza, persuadían con mucha instancia a los con quien trataban que creyesen en sus dioses falsos y los suyos verdaderos, y aún acá en las Indias pocos tiempos antes que los españoles entrasen en Perú reinando en aquellos reinos un bárbaro dicho Guaynacapa, con la ambición que de reinar tenía, hizo guerra a muchas gentes muy apartadas de sus reinos y a todos los que sujetaba les inducía y persuadía a que dejando su lengua materna y la idolatría de sus imaginativos dioses creyesen en los suyos, que él tenía por verdaderos (Aguado 1915: 245).

Las hipótesis sobre una posible expansión peruana que alcanzaría los Andes y el litoral venezolanos sigue siendo materia de debate. Sin embargo, en la alfarería sí se evidencian algunas trazas estilísticas comunes entre los Andes y las culturas del Orinoco, por ejemplo, entre la orinoquense Barrancoide (fig. 6) y la andina Santa Ana (fig. 7).

\section{Iconografías y lenguajes visuales no-escultóricos}

A pesar de no compartir la misma proliferación de estatuillas contextualizadas en prácticas ceremoniales, sí identificamos iconografías similares en las vasijas y otros objetos utilitarios. Del mismo modo, norte y sur comparten otras prácticas culturales, como costumbres funerarias y la deformación craneal. Así lo evidencian las excavaciones dirigidas por Gaspar Marcano de finales del siglo xix no solo en los valles de Aragua, sino también a lo largo del Orinoco. En el Estado Bolívar se realizaron, por ejemplo, diversas exhumaciones en cementerios Maipure (de afiliación lingüística Arawak) ${ }^{10}$ que determinaron la presencia de deformaciones sobre todo en los cráneos femeninos (aunque en menor cantidad, también se hallaron deformaciones masculinas) (Marcano 1971: 195). Por lo demás, debemos tener en cuenta que las deformaciones craneales conformaron una práctica sumamente extendida y documentada en culturas dispersas por toda la América prehispánica, por lo que formó parte de los más variados tipos de culto. Como venimos exponiendo en el presente apartado, las costumbres funerarias tampoco parecen responder a esta diferencia entre un culto idolátrico y otro imbricado en objetos funcionales (tanto rituales como cotidianos), puesto que tanto en el norte como en el sur se realizaron inhumaciones y dobles funerales.

En sus prospecciones por el actual Estado Bolívar, Marcano encontró evidencia de la práctica del doble funeral en diversas cuevas y debajo de las hendiduras de grandes lajas (Marcano 1971: 158). Allí identificó funerales en urnas, así como momificaciones envueltas en hojas de plátano y cestas. Las urnas representaban figuras zoomorfas -cocodrilos o serpientes- y estaban decoradas con sinuosas grafías abstractas materializadas en formas de "meandros y laberintos". En su interior, los huesos habían sido depositados de manera ordenada y estaban pintados con onoto (pigmento rojo extraído de la Bixa orellana) (Marcano 1971: 159).

Es decir que, según la evidencia arqueológica e histórica, existieron múltiples prácticas rituales y cotidianas comunes entre las culturas que habitaron el septentrión venezolano y el sur del Orinoco. Ahora bien, Marcano no parece haber hallado ni hace mención alguna de estatuillas de cerámica en el sur, como aquellas que abundaban en los contextos funerarios del litoral y los Andes. Reproducimos las palabras del autor, quien se asombró por la ausencia de cualquier tipo de representación simbólica en torno a la muerte en los contextos funerarios:

No se ve nada en esas urnas que evoque el recuerdo, la pena; nada que indique las plegarias, ni la intención de conservar su memoria. Apenas la idea de otra vida está representada por las urnas votivas, después de todo muy raras y llenas de objetos insignificantes. En una palabra, parece que se cumplía con todos los deberes hacia el difunto cuando se había puesto su cráneo a buen recaudo (Marcano 1971: 245). 
Sin embargo, insistimos en que si bien no se encontraron ídolos como los del septentrión venezolano, en las regiones sureñas se evidencian múltiples formas zoomorfas y antropomorfas que sobresalen de las vasijas y coronan las tapas de las urnas funerarias. Del mismo modo, abundan entre las comunidades indígenas actuales de la Guayana y el Amazonas diversos tipos y estilos de pinturas -utilizadas en el cuerpo, en las cestas, etc.- que demuestran la existencia de otro tipo de noción icónica (Taylor 2008).

Aunque no poseemos evidencia directa de la presencia de estatuillas de cerámica en los escritos de expediciones en Venezuela, hemos localizado en los diarios de viaje de Jules Crevaux por la Guayana francesa (de la segunda mitad del siglo xIx) la presencia de un maniquí hecho de fibras vegetales que representaba un guerrero (Crevaux 1987: 328). Así pues, pese a la carencia de figuras realizadas con arcilla o materiales más duraderos, sí existe evidencia de un cierto tipo de "ídolos", aunque realizados con materiales orgánicos de fácil descomposición y particularmente sensibles a las condiciones climáticas tropicales. Asimismo, encontramos la figura del damodede (conocida en castellano como el Pensador, fig. 9), forma doble de un hombre o mono que representa al demiurgo de la sociedad Ye'kuana de habla Caribe y que podría ser una continuación icónica de algún tipo de figura divina venerada en el pasado en las regiones guayanesas. ${ }^{11}$ Cabe destacar que dicha figura suele encontrarse en la mayoría de los casos imbricada en algún objeto votivo, como en el mango de una maraca o de un arma ritual.

La escasa información sobre el origen de aquella figura se debe a que la mención más antigua sobre estas imágenes en regiones venezolanas se halla en los escritos y diseños de Theodor Koch-Grünberg, de inicios del siglo xx. En estos identificamos una descripción de la figura doble imbricada en el mango de una maraca mágica que el explorador encontró entre los "Irahana" - "Las dos figuritas representan "hombres que viven por encima de nuestro cielo"' (Koch-Grünberg 1979: 292)-. ${ }^{12}$ El Pensador es una figura crucial en los mitos ye'kuana actuales. Sin embargo, aún no ha sido posible dilucidar con exactitud por qué no comenzamos a ver este ícono antes del siglo xx entre las culturas Caribe de la Guayana venezolana: ¿fue una adquisición reciente de estos pueblos del norte o bien se trata de una práctica ancestral guayanesa o amazónica cuyos vestigios arqueológicos no lograron sobrevivir hasta el presente?

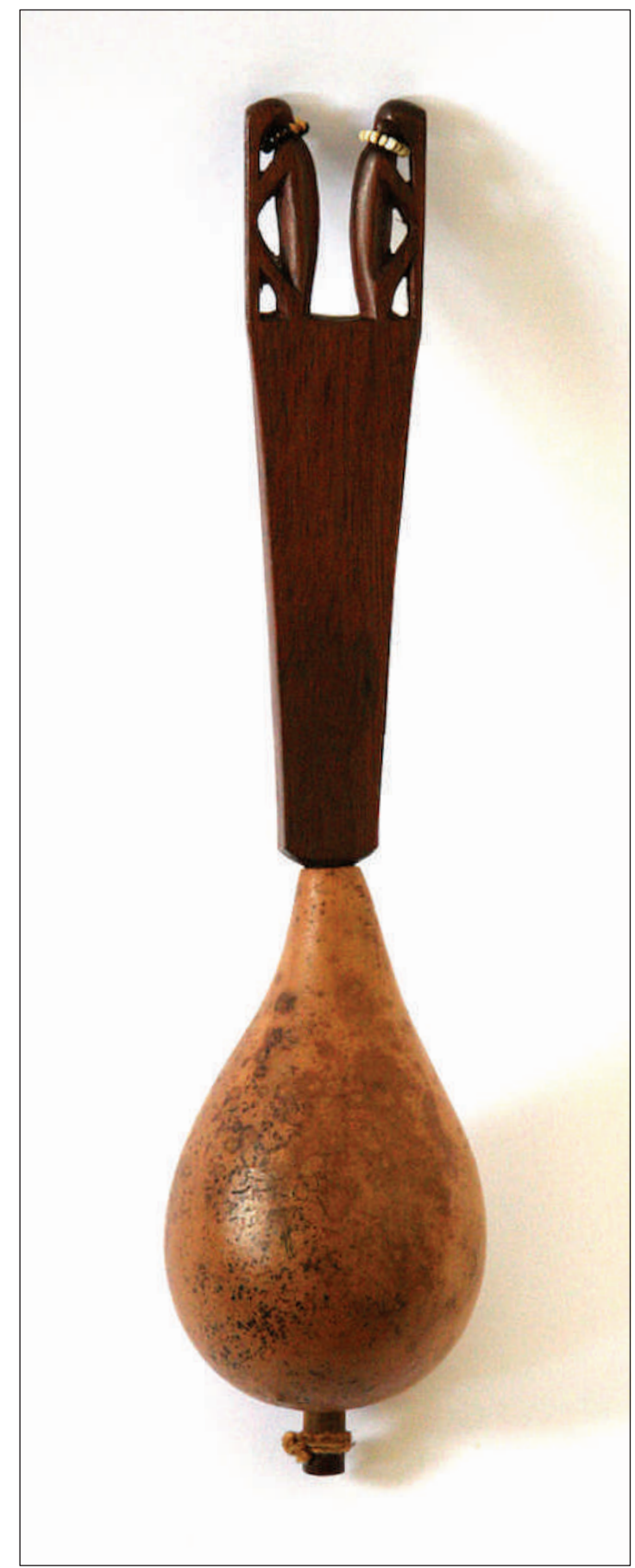

Figura 9. Maraca Ye'kuana con imagen del damodede o Pensador en el mango. Tapara, madera, piedras $30 \mathrm{~cm}$ de largo, Estado Amazonas. Colección Etnográfica ICAS, Fundación La Salle, Caracas (fotografía de la autora). Figure 9. Ye'kuana maraca with the image of the "damodede" or "thinker" in the handle. Gourd, wood, stones $30 \mathrm{~cm}$ length, state of Amazonas. ICAS Ethnographic Collection, Fundación La Salle, Caracas (photo by the author). 


\section{CONCLUSIONES}

En suma, en este artículo hemos intentado individuar distintos horizontes iconográficos en territorio venezolano entre el período prehispánico y el presente, de los cuales destacamos una remarcada diferenciación entre las regiones del norte (la zona costeña y sus inmediaciones, de oriente a occidente) y las del sur (a lo largo del Orinoco, en la Guayana y el Amazonas). Por un lado, observamos en el septentrión una proliferación de estatuillas votivas, principalmente de cerámica, que podrían indicar un tipo de antropocentrismo que se divide a su vez en dos tipologías iconográficas, la femenina y la chamánica. En todo caso, el tipo de manifestación visual desarrollada en el norte corresponde a un culto profesado hacia símbolos antropomorfos y zoomorfos y, por tanto, a una relación específica con lo sagrado que no existió en las regiones al sur del Orinoco (la Guayana y el Amazonas) -al menos no con la misma proliferación.

Por otro lado, las regiones al sur del Orinoco se caracterizaron por poseer una iconicidad más abstracta, cuya concepción simbólica no materializa un intercesor figurativo entre el hombre y lo divino. Así, su imaginería se mantiene imbricada en objetos funcionales y sus símbolos visuales se sintetizan en patrones geométricos. $\mathrm{Si}$ bien algunas de estas culturas sí poseyeron una compleja iconografía de formas intrincadas que entremezclan motivos antropomorfa y zoomorfa -como las series Salaloide y Barrancoide-, esta nunca se encuentra materializada en forma de estatuillas, sino como ornamentación de las vasijas y otro tipo de ajuar votivo y utilitario.

A pesar de todo, existió una correspondencia conceptual entre las sociedades del norte y las sociedades del Amazonas y la Guayana: a su manera, ambas recurrieron a un tipo de representación de lo sagrado que remite a divinidades y figuras metamórficas que, en ocasiones, parece corresponder a ciertos tipos de prácticas chamánicas. Este imaginario simbólico encontró diversos medios de representación a través de los mitos orales, las formas puramente geométricas en la cestería, la alfarería y la pintura corporal, así como las figuras votivas y los ornamentos claramente antropomorfos y zoomorfos. Po tanto, mientras que un tipo de horizonte iconográfico materializa estas estatuillas de forma independiente y desgajada de un contexto utilitario, el otro se manifiesta en todos los objetos culturales y no busca representarse de manera aislada.
Las evidencias arqueológica e histórica en las regiones venezolanas nos han llevado a determinar que en período prehispánico se desarrollaron diversas prácticas votivas que respondían a distintos horizontes iconográficos, los que fueron independientes de los movimientos de grupos lingüísticos y de los grupos culturales asociados a estilos de alfarería. Estas diferencias podrían señalar la presencia de diferentes ontologías visuales o formas de entender el mundo simbólico que derivan en distintas prácticas rituales.

Dichas diferencias también se hallan en las crónicas históricas, ya que los colonos reconocían en el norte de Venezuela la existencia de idolatría mientras que en el sur no. Recordemos que los objetos de la época prehispánica que sobrevivieron la intrusión colonial cumplían en su gran mayoría una función utilitaria; estos serían por ejemplo las cestas para el procesamiento de alimentos, la cerámica como contenedora de bebidas y comidas, las hamacas, las canoas, las viviendas, algunos instrumentos musicales, etc. Hablamos aquí de algunos quehaceres que la tradición cristiana inscribía exclusivamente en el mundo de lo profano, pero que para el mundo amerindio guardarían un valor simbólico y religioso igual de sustancial (aunque distinto) que el de aquellos objetos confeccionados para los cultos. Así pues, las representaciones y decoraciones visuales contenidas de estos objetos supervivientes eran en general de carácter abstracto: las figuras zoo y antropomorfas estaban estilizadas con tal capacidad sintética que se hacía difícil percibir en ellas un simbolismo particular, por lo que fueron consideradas como simples "ornamentos" carentes de significado.

Precisamente, la visión desacralizada que tuvieron los colonizadores en el sur del Orinoco habría permitido que las formas simbólicas referentes a lo sagrado pudieran sobrevivir hasta el presente con mayor facilidad que las manifestaciones votivas del norte, calificadas por la perspectiva cristiana como idolátricas. Así, mientras que en el presente ya no encontramos sociedades indígenas que posean este tipo de estatuillas votivas (correspondientes a las prácticas del norte), sí encontramos simbolismos mítico-religiosos entretejidos en los patrones geométricos de la cestería, los diseños de la pintura corporal, los rituales y prácticas musicales actuales.

La permanencia de los horizontes iconográficos del sur del Orinoco fue posible gracias a aquellas formas que los europeos veían como profanas. Otros elementos pertenecientes de manera más evidente al ritual, como 
los ornamentos corporales y los instrumentos musicales, pasarían lentamente por un proceso de desacralización. En muchas ocasiones, dichos elementos serían vaciados de sus contenidos religiosos tradicionales, para adoptar una funcionalidad profana. Sin embargo, esta visión desacralizada del mundo ayudaría precisamente a la preservación de ciertas tradiciones ancestrales entre las comunidades amerindias, ya que no fueron vistas por los colonos como insignias de una identidad cultural y religiosa, sino como simples objetos utilitarios. Todas estas formas y objetos estaban muy lejos de carecer de un complejo contenido simbólico, el cual no solo alude a un orden y a una estructura social específica sino también a una cosmogonía particular. Así, la mirada desacralizada de este mundo serviría como un manto de invisibilidad que impediría su erradicación y sustitución completa por nuevas costumbres.

\section{NOTAS}

${ }^{1}$ Traducción de la autora.

${ }^{2}$ Nos referimos a los estudios de Philippe Descola (2005) en los que describe cómo el hombre humaniza o culturaliza la naturaleza y se distingue del estado "salvaje" a través de sus atuendos corporales.

${ }^{3}$ Es necesario alertar sobre el hecho de que las fuentes históricas por medio de las cuales se ha intentado esclarecer el pasado prehispánico y el período de contacto con el europeo presentan variaciones considerables entre ellas, así como peligros de interpretación: en primer lugar, dependemos del juicio del cronista, lo cual deja en duda si las descripciones son fidedignas. En segundo lugar, suelen confundir las diversas épocas y regiones descritas, lo que dificulta bastante la vinculación de las sociedades mencionadas con yacimientos arqueológicos específicos.

${ }^{4}$ Hay evidencia de estos ataques iconoclastas hacia la imaginería indígena por parte de misioneros. Kleiss (1967: 9) hace mención, por ejemplo, de una gran quema de 1114 santuarios, chozas e ídolos indígenas (Timoto-Cuicas) por manos del Obispo Zapata de Cárdenas en 1608. De la misma manera, documenta actos iconoclastas similares en Bogotá y otras regiones andinas.

${ }^{5}$ Según las descripciones de Jahn (1973), hasta entrado el siglo XIX existían diversos pueblos indígenas en el noroccidente del país (Estados Lara y Falcón), como los Jirajaras, Ayomanes, Ajaguas y Gayones, los cuales se habían reducido considerablemente a comienzos de siglo y hoy se pueden considerar definitivamente extintos: "Hasta el año 1910 quedaba uno que otro individuo descendiente de las antiguas tribus y poseedor del dialecto de sus antepasados. Por los años
1880 debió existir un remanente mucho más numeroso de estos indios" (Jahn 1973: 20).

${ }^{6}$ Menciona, entre otros, a los Jirajaras, los Achaguas, los Caquetíos (Arawak), los Cuybas, Guaycaríes, etc.

7 "Las primeras evidencias de ocupaciones neoindias o agroalfareras se encuentran en el Estado Lara, asociadas con la serie Tocuyanoide, alrededor de los 300 A.c." (Arvelo \& Oliver 1999: 125).

${ }^{8}$ Antczak y Antczak (2006) escudriñan la información contenida en distintas crónicas y escritos de la Colonia (Pimentel, Oviedo y Baños, Antonio Herrera y Tordesillas, entre otros) sobre el área norcentral de Venezuela y específicamente las menciones a los indios Caracas. En este caso, no leemos que los "ídolos" femeninos formaran parte de su acervo. Además, estos parecieron diferenciarse de otros pueblos que habitaban las islas del lago de Valencia, y los autores se preguntan por ejemplo si estos últimos (y no los Caracas) fueron "la reminiscencia de la élite o "los señores Valencioides" (Antczak \& Antczak 2006: 507, 510-511, 514).

${ }^{9}$ De acuerdo con otros misioneros de su época, Gumilla (1963: 301) pensaba que estos pueblos indígenas provenían de los judíos.

${ }^{10}$ Excavaciones en el cerro de Luna, en el Estado Bolívar (Marcano 1971).

${ }^{11}$ Recordamos que los caribes parecen asentarse en la Guayana a partir del segundo milenio AC aproximadamente, dividiéndose de los grupos caribe del norte que más adelante desarrollarían las complejas representaciones de las Venus en el área de Valencia (Tarble 1985: 65).

${ }^{12} \mathrm{El}$ autor refiere a una figura del doble Pensador representada en Koch-Grünberg (1979: 265, tabla 49, fig. 6).

\section{REFERENCIAS}

Aguado, P., 1915. Historia de Venezuela. Escrita en 1581 por Fray Pedro de Aguado. Caracas: Academia Nacional de la Historia.

Antczak, A. \& M. Antczak, 2006. Los ídolos de las Islas Prometidas. Arqueología prehispánica del Archipiélago de Los Roques. Caracas: Equinoccio.

Arvelo, L., 1999. La cuenca del lago de Maracaibo. En El arte prehispánico de Venezuela, M. Arroyo, L. Blanco \& E. Wagner, Eds., pp. 106-119. Caracas: Fundación Galería de Arte Nacional-Ex Libris.

Arvelo, L., 2000. Change and persistence in aboriginal settlement patterns in the Quíbor Valley, northwestern Venezuela (sixteenth to nineteenth centuries). Ethnohistory 47 (3-4): 669-704.

Arvelo, L. \& J. Oliver, 1999. El noroccidente de Venezuela. En El arte prehispánico de Venezuela, M. Arroyo, L. Blanco \& E. Wagner, Eds., pp. 120-135. Caracas: Fundación Galería de Arte Nacional-Ex Libris.

Belting, H., 2005. La vraie image. París: Gallimard. 
BioRD-CASTILLO, H., 2005. Sistemas interétnicos regionales: el Orinoco y la costa noreste de la actual Venezuela en los siglos XVI, XVII y XVIII. Historia Regional. Mérida: Universidad de Los Andes. < http://www.saber.ula.ve/ bitstream/123456789/27523/1/sistemas-interetnicos.pdf> [Consultado 22-06-2017].

Crevaux, J., 1987. Le mendiant de l'Eldorado. De Cayenne aux Andes. París: Phébus.

Descola, P., 2005. Par-delà nature et culture. París: Gallimard.

Federmann, N., 1916. Narración del primer viaje de Federmann a Venezuela. Caracas: Lit. y Tip. del Comercio.

Gassón, R., 2000. Quirípas and mostacillas: the evolution of shell beads as a medium of exchange in northern South America. Ethnohistory 47 (3-4): 581-609.

Gumilla, J., 1963. El Orinoco ilustrado y defendido. Caracas: Academia Nacional de Historia.

Heinen, D. \& A. García-Castro, 2000. The multi-ethnic network of the lower Orinoco in early colonial times. Ethnohistory 47 (3-4): 561-579.

JAHN, A., 1973. Los aborígenes de occidente de Venezuela. Su historia, etnografía y afinidades lingüisticas, tomo II. Caracas: Monte Ávila.

KLEIss, E., 1967. Fruchtbarkeitsidole der Timoto-Cuicas: Ein Beitrag zur Kenntnis der frühen venezolanischen Medizin- und Kulturgeschichte. En Sudhoffs Archiv, Band 51, Heft 1. März.

Koch-Grünberg, T., 1969. Anfänge der Kunst im Urwald: indianer-handzeichnungen auf seinen reisen in brasilien gesammelt. Oosterhout: Anthropological Publications.

Koch-Grünberg, T., 1979. Del Roraima al Orinoco. E. Armitano, Ed., tomo III. Caracas: Ediciones del Banco Central de Venezuela.

Marcano, G., 1971. Etnografía precolombina de Venezuela. Caracas: Universidad Central de Venezuela.

PAnofsky, E., 1989. Idea. Contribución a la historia de la teoría del arte. Madrid: Cátedra.

PAnofsky, E., 2006. Estudios sobre iconología. Madrid: Alianza.

Rouse, I. \& J. M. Cruxent, 1963. Venezuelan archaeology. En Caribbean Series, 6. New Haven-Londres: Yale University Press.

Rouse, I., 1989. Peoples and cultures of the Salaloid Frontier in the Greater Antilles. En Early ceramic population lifeways and adaptive strategies in the Caribbean, P. Siegel, Ed. Oxford: BAR International Series 506.

TARble, K., 1985. Un nuevo modelo de expansión Caribe para la época prehispánica. En Antropológica, 63-64, pp. 45-81. Caracas: Fundación La Salle de Ciencias Naturales.

TAYlOR, A., 2008. Arte y mito en las culturas amazónicas. Conferencia presentada en Jornadas de Arte y Mito 2008, Centro Investigador en Arte Primitivo y Primitivismo. Barcelona: Universidad Pompeu Fabra, 10 de Marzo. $<$ https://www.upf.edu/documents/3192920/0/Conferencia_Taylor_Amazonas_peq.pdf/455cbc03-a314-4cb7-ad53a7e2051d97db> [Consultado 19-06-2017].
TAYLOR, A., 2011. La nature des images dans l'animisme amazonien. En La fabrique des images. Visions du monde et formes de la représentation, P. Descola, Dir. París: Musée du quai Branly.

Viveiros de CAstro, E., 1992. From the enemy's point of view. Humanity and divinity in an Amazonian society. ChicagoLondres: University of Chicago Press.

Viveiros de Castro, E., 2010. Metafísicas caníbales. Líneas de antropologia postestructural. Buenos Aires: Katz.

Viveiros de Castro, E., 2002. A inconstância da alma selvagem. São Paulo: Cosac \& Naify.

Von Humboldt, A., 1826. Viage á las regiones equinocciales del Nuevo continente. París: En casa de Rosa.

WAGNER, E., 1999. La región andina. En El arte prehispánico de Venezuela, M. Arroyo, L. Blanco \& E. Wagner, Eds., pp. 90-105. Caracas: Fundación Galería de Arte Nacional-Ex Libris.

Whitehead, N., 1988. Lords of the tiger spirit. A history of the Caribs in colonial Venezuela and Guyana. 1498-1820. Dordrecht-Providence: Foris Publications.

Willey, G., 1945. Horizon styles and pottery traditions in peruvian archaeology. American Antiquity 11 (1): 49-56. 